Jap. J. M. Sc. \& Biol., 11, 21-29, 1958

\title{
ON THE CERCARIA OF CENTROCESTUS ARMATUS (TANABE, 1922) YAMAGUTI, 1933, ESPECIALLY ON ITS MUCOID GLAND (HETEROPHYIDAE, TREMATODA)
}

\author{
JiRo ITO AND KYozo WATANABE \\ Department of Hygiene, Faculty of Education, Shizuoka University, \\ Shizuoka, Japan
}

(Received: January 30 th, 1958)

This cercaria has been observed and described by earlier Japanese investigators. Initial report was made by Yoshida (1917), and two subsequent reports by Kobayashi (1918) and Ando (1918). In 1922 Kobayashi summarized the above mentioned cercariae as "Cercaria flavopunctata B", and Faust (1924) named it Cercaria picta. Later on Takahashi (1929) proved that this cercaria developed to Stamnosoma armatus Tanabe, 1922, which was renamed as Centrocestus armatus by Yamaguti in 1933. Yamaguti (1938) also reported its detailed morphology with the confirmation of its life history.

A series of reports about the mucoid gland of American cercariae were published by Kruidenier (1951, etc.). Recently Yokogawa and Yoshimura (1956) also reported about the mucoid gland of the cercaria of Japanese lung fluke, Paragonimus westermanii. The discovery of a series of metachromatic cells, so called "mucoid gland" in the cercariae by Kruidenier may help not only the study of the physiology of cercariae but also the evaluation of the classification and phylogeny of trematodes.

The authors had opportunities of getting the cercariae from the fresh water snails at several areas in Japan, and it was identified as the cercaria of Centrocestus armatus as a result of feeding experiments on gold fish. In the course of the investigation of the morphology of the cercariae, studies of "mucoid gland" were carried on. The followings are the detailed description of the morphology, especially of the mucoid gland of the cercaria, with a report of geographical distribution and its infection rate.

\section{Materials AND Methods}

Cercariae and radiae were obtained by crushing the snail host, Semisulcospira spp., or by making them to emerge from the host in natural way. Living materials taken in $0.4 \%$ $\mathrm{NaCl}$-solution were much convenient for observing its general structures, and vital staining with neutral red was helpful for some detailed structures. The measurements were

伊藤二郎・渡辺强三 (静岡大学教育学部保健教室) 
taken on materials fixed in $10 \%$ hot formalin. All drawings were made to scale from such measurements.

The mucoid glands were not detected by the above mentioned living material, but by staining with metachromatic dyes, such as toluidin blue or thionin, as employed by Kruidenier. Various developmental stages of cercariae, including the immature ones obtained from carefully dissected rediae, were smeared on a slide glass with egg albumin. These preparations were fixed in Schaudinn's solution or saturated aqueous corrosive sublimate, then washed in absolute alcohol. A part of toluidin blue or thionin dissolved in 2000 parts of $30 \%$ alcohol was employed to stain the mucoid gland which indicated a brilliant metachromatic red in contrast with orthochromatic blue of general tissues of cercaria. The staining preparation was mounted in balsam after passing alcohol and xylol. The metachromatic reaction persisted through alcoholic dehydration and was retained indefinitely by permanently mounted specimen for more or less long time.

\section{Geographical Distribution of the Cercaria}

Two species of fresh water snails, Semisulcospira libertina (Gould) and $S$. reiniana (Brot) were infected with this cercaria, The infection rate of the cercaria in these snails in several areas in Japan, the observation being made for a period of years from 1946 to 1957, was shown in Table 1. The highest infection rate

Table 1. The geographical distribution of cercaria of Centrocestus armatus in Japan

\begin{tabular}{|c|c|c|c|c|c|}
\hline Locality & Snail host & Date & $\begin{array}{c}\text { Number } \\
\text { examined }\end{array}$ & $\begin{array}{l}\text { Number } \\
\text { infected }\end{array}$ & Percentage \\
\hline $\begin{array}{l}\text { Edo River } \\
\text { Tokyo }\end{array}$ & $\begin{array}{l}\text { Semisulcospira } \\
\text { reiniana }\end{array}$ & $\begin{array}{l}\text { Oct. } 1946- \\
\text { Sept. } 1948\end{array}$ & 1488 & 5 & 0.3 \\
\hline $\begin{array}{c}\text { Nameri River } \\
\text { Kanagawa }\end{array}$ & S. libertina & July 1950 & 130 & 0 & \\
\hline $\begin{array}{l}\text { Nakakoma-gun } \\
\text { Yamanashi }\end{array}$ & S. libertina & $\begin{array}{l}\text { May } 1947- \\
\text { May } 1951\end{array}$ & 1892 & 3 & 0.16 \\
\hline $\begin{array}{l}\text { Hatta-gun } \\
\text { Kochi }\end{array}$ & S. japonica & $\begin{array}{l}\text { Jan. } 1950- \\
\text { Feb. } 1950\end{array}$ & 882 & 0 & \\
\hline Ehime Pref. & S. japonica & May 1949 & 546 & 0 & \\
\hline $\begin{array}{l}\text { Kano River } \\
\text { Shizuoka }\end{array}$ & S. libertina & $\begin{array}{l}\text { Oct. } 1948- \\
\quad \text { Nov. } 1950\end{array}$ & 9240 & 4 & 0.04 \\
\hline $\begin{array}{l}\text { Shizuoka City } \\
\text { Shizuoka }\end{array}$ & S. libertina & June 1956 & 254 & 85 & 33.5 \\
\hline $\begin{array}{l}\text { Various areas } \\
\text { in Shizuoka }\end{array}$ & S. libertina & $\begin{array}{l}\text { May } 1956- \\
\text { Nov. } 1956\end{array}$ & 3012 & 34 & 1.1 \\
\hline Ditto & S. libertina & $\begin{array}{l}\text { Feb. 1957- } \\
\text { Aug. } 1957\end{array}$ & 8746 & 26 & 0.3 \\
\hline & Total & & 26590 & 157 & 0.58 \\
\hline
\end{tabular}

was observed in the snails collected from Shizuoka City. Eighty-five out of 254, or $33.5 \%$ of snails from the City were infected with this cercaria. In the other localities the infection rate was about $1 \%$ or less than $1 \%$. Table 2 showed the percentages of infection with the cercariae in relation to the size of snail hosts, which indicated no clear relationship between the infection rate and the size of the snail host. 
Table 2. Correlation of infectivity rate of cercaria of Centrocestus armatus with the length of snail host

\begin{tabular}{rrcc}
\hline $\begin{array}{c}\text { Length of } \\
\text { snail host }\end{array}$ & Number examined & Number infected & Percentage \\
\hline Under $10 \mathrm{~mm}$ & 442 & 0 & - \\
$11-15 \mathrm{~mm}$ & 2406 & 11 & 0.46 \\
$16-20 \mathrm{~mm}$ & 4942 & 13 & 0.26 \\
$21-25 \mathrm{~mm}$ & 6965 & 36 & 0.52 \\
$26-30 \mathrm{~mm}$ & 6175 & 55 & 0.89 \\
$31-35 \mathrm{~mm}$ & 3265 & 21 & 0.64 \\
$36-40 \mathrm{~mm}$ & 1209 & 11 & 0.91 \\
$41-45 \mathrm{~mm}$ & 94 & 6 & 6.37 \\
\hline
\end{tabular}

\section{General Features of the Cercaria}

Redia (Fig. 1) - The parthenitae are rediae which are colourless, with the exception of the brownish coloured intestine. The youngest rediae are $0.1 \mathrm{~mm}$ long and the mature ones are not more than $0.5 \mathrm{~mm}$, the length of the others

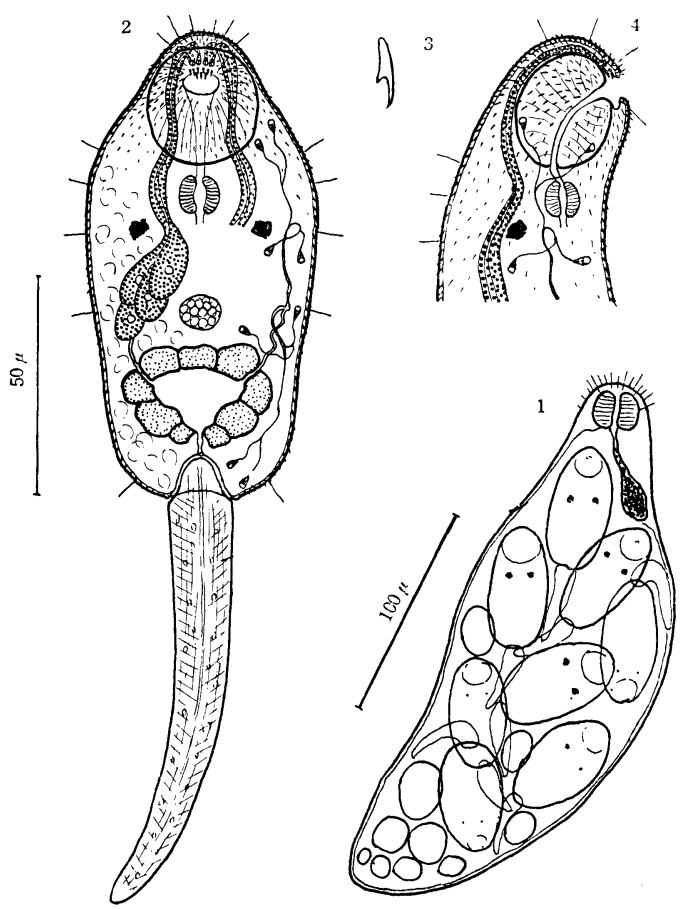

Fig. 1. The cercaria of Centrocestus armatus, half-diagrammatic drawing omitting the penetration gland on the right side, and the excreotry pattern on the left side.

Fig. 2. One of the oral spine, powerfully enlarged.

Fig. 3. Lateral view of the anterior part of cercaria.

Fig. 4. The redia containing various developmental stages of cercaria. 
being between these two extremes. They are somewhat irregular ellipsoid in shape, tapering anteriorly and posteriorly. Neither collar nor locomotive processes are seen. At the anterior part of the body surface is beset with many sensory hairs with the length of $c a .2 \mu$. A well developed pharynx, about $24 \times 21 \mu$, is succeeded by a rhabdocoele intestine which is very short and occupies a very small part of the body. In the body cavity of redia about 20-30 cercarial embryos of various developmental stages are contained, some of them are so developed that the eye spots of cercariae are already detectable.

Cercaria (Figs. 2, 3, 4 and 5) - The cercaria is a incessant swimmer and comes together at the light side of the glass bottle with prominent phototaxis. The

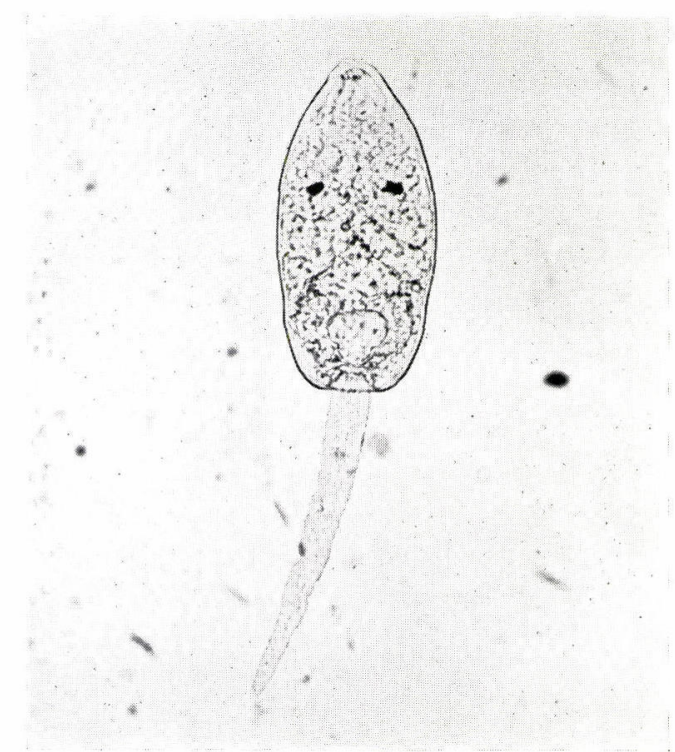

Fig. 5. The cercaria of Centrocestus armatus, raw material without any staining.

body is a comparatively small in size, elongated oval in shape, its posterior part being more blunt than its anterior. The measurements made on twenty cercariae fixed with $10 \%$ hot formalin are as follows.

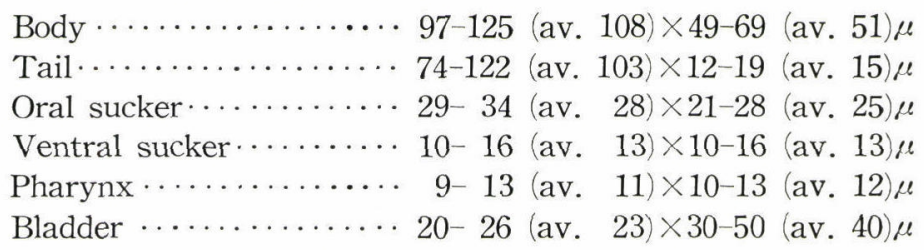

The body surface is furnished with many minute spines arranging most densely at the margin of mouth opening. There are another large type of double pointed nine spines (Fig. 3) which is called as "oral spines." These oral spines, 4-6 $\mu$ in length, are embedded in dorsal side of mouth opening arranging alternatively in two rows, the anterior row of 6 spines and posterior one of 3 spines. The 
body surface is also beset with several pairs of sensory hairs standing on a minute papilliform base respectively. The number of these sensory hairs is not constant because of their frailness, sometimes 8 pairs and sometimes nothing can be observed.

Though the cercarial body has a small amount of brownish pigmented granules, it is comparatively transparent. A moderatory developed oral sucker opens at the anterior ventral end of the body. The acetabulum, situated slightly posteriorly on the median ventral part of the body, is very faintly developed and is hardly recognizable. The mouth is anteroventral and leads into a short prepharynx which is followed by the weakly developed pharynx. The esophagus and intestines can not detect even in the mature cercariae. Four pairs of penetration gland cells are arranged at the middle part of the body. Their ducts run together forwards turning around the dorsal side of the oral sucker, then open at the dorsal side of the mouth through four openings composed of two ducts respectively. At the level behind the pharynx are one pair of pigmented eye spots which are not so well developed but relatively conspicuously observable. The cystogenous gland cells scatter on the inner side of the body surface except its anterior part.

The posterior part of the body is occupied by a thick walled large excretory bladder. Its wall is lined with a thick layer of cuboid epithelia of about nine cells. From the antero-lateral corner of the bladder, two main excretory collecting tubes run forwards in a short distance, dividing into anterior and posterior collecting tubes respectively at the both side of the acetabulum. The number of flame cell is 8 pairs, namely two pairs at the both side of the oral sucker, next two pairs at the slightly posterior side of eye spots, the third two pairs at the anterior side of the excretory bladder and the last two pairs are at the posterior end of the body. Thus the flame cell formula is constructed as follows :

$$
2[(2+2)+(2+2)]=16
$$

The tail is connected with a deep groove at the ventral posterior end of the body. The length is as long as that of the body, and is devoid of any appendages such as spine, hair and fin.

\section{Mucoid Gland and Its Development (Figs. 6 and 7)}

Besides possessing the penetration and cystogenous glands, this cercaria has a series of unicellular mucoid glands. These cells are not observed in raw materials but in stained ones with toluidin blue or thionin. Then the cells are stained as brilliant metachromatic red in contrast with blue of somatic tissue.

The most developed and typically arranged mucoid glands are always observed in the cercariae within the redia, and not in the cercariae outside of the redia (Fig, 6, f). The cytoplasma of the mucoid gland cells look like homogenous. Sometimes the nucleoli can be observed in their large nuclei. These cells are paired and lie in a parallel series along the mid-ventral axis of the cercariae. They never penetrate very deeply into the cercarial tissues, but located near the ventral surface of the body (Fig. 6, g). Total five pairs of such mucoid glands extend from the level of eye spots to the posterior end of the body. Among them, four pairs are located between the eye spots and the acetabulum and one pair forms posterior to the latter organ. The most anterior pair of glands which 
is the largest in size as compared with the other, are situated at the inner side of the eye spots. Sometimes the fragments of metachromatic secretions are observed at the anterior of them. Such fragments look like their ducts but their course can not determine in this cercaria. The glands posterior to the acetabulum possess enlarged ducts. These lead posteriad, encircle a slight depression at the base of the tail and empty marginally on either side of the body.

The progressive development of the mucoid glands is as follows. The most immature cercarial germ ball within the redia shows neither internal structure nor the mucoid gland (Fig. 6, a). The initial appearance of the first one pair of

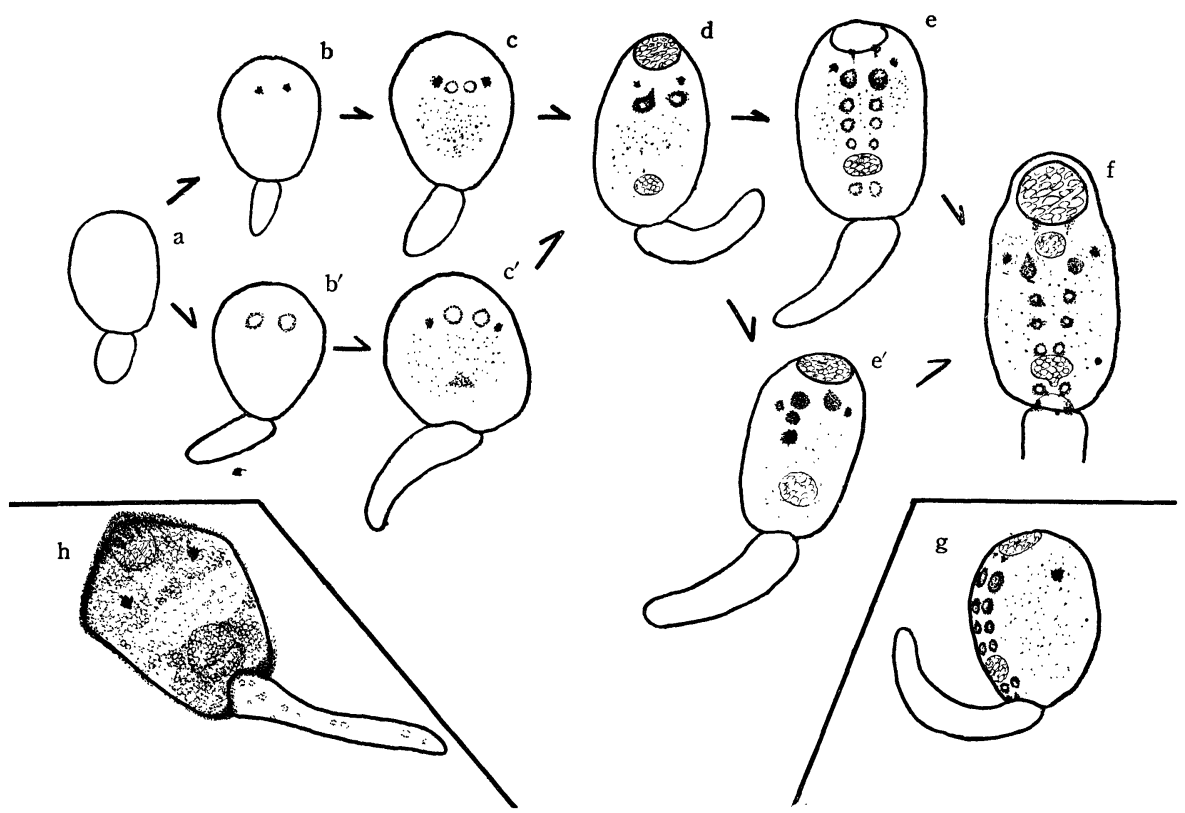

Fig. 6. Developmental stages of mucoid glands of the cercaria. gures are Fithe cercariae within the redia, except the last one. Fixed in Schaudinn's solution and stained in toluidine blue preparations.

$a$, The immature cercaria showing nothing of the internal structure. $b$ and $c$, The initial apperarance of mucoid glands after the development of eye spots. $b^{\prime}$ and $c^{\prime}$, Ditto prior to the develompnent of eye spots. $d$, The differentiation of oral sucker and excretory bladder and the parallel enlargement of the first pair of mucoid glands. $e$, The appearance of other posterior four pairs of mucoid glands, the last one is at the posterior to bladder. $e^{\prime}$, The appearance of a part of them. $f$, The fully developed mucoid glands. Note the mucoidal reservoirs at the positions between oral sucker and pharynx, and the posterior end of body. $g$, Lateral view showing the ventral position of the mucoid glands. $h$, Discharged mucoid substance at the body surface of cercaria outside of redia, pre-emergent one. Note the thickest mucoid film at the anterior and posterior part of the body surface.

mucoid glands is observed prior (Fig. 6, $\mathrm{b}^{\prime}$ and $\mathrm{c}^{\prime}$ ) or after (Fig. 6, b and c) the development of eye spots. This pair of glands increases its size while the another pairs not yet appear (Fig. 6, d). After a while the another four pairs of mucoid glands or a part of them appear simultaneously in a parallel series along the midventral axis of the cercaria (Fig. 6, e and é, Fig. 7). These cells mature rapidly and are filled with mucoid substance (Fig. 6, f). 
The above mentioned various developmental stages of cercariae are all compacted within the redia. On the contrary, in the cercariae outside of redia whether the cercariae are pre-emergent or emergent one, these serial mucoid gland cells disappear. In such cercariae a thin highly metachromatic film over the body

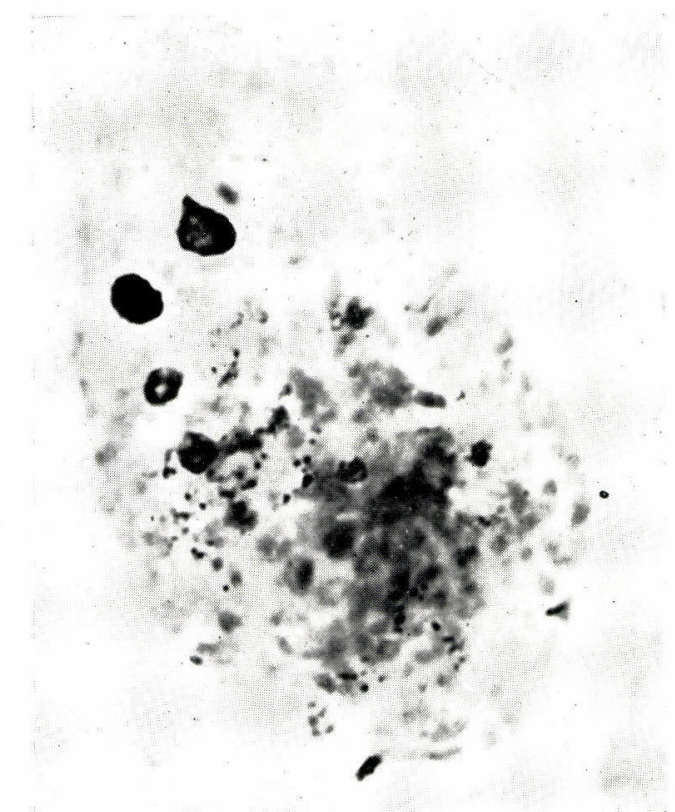

Fig. 7. The cercarial body, fixed in Schaudinn's solution and stained in toluidine blue. Note the sharply differentiated four mucoid gland cells. (Refer to Fig. 5, e')

surface is observed instead of the mucoid glands. The metachromatic film of preemergent cercaria is much thicker than that of emergent one, on which only a portion of such film is demonstrable. Sometimes the emergent cercariae show scarcely such film. Though there are many variations in each pre-emergent cercariae, the thickness of this film is thicker arround the anterior and posterior end of the body (Fig. 6, h). The large number of older, apparently mature cercariae in the snail tissue, outside of but near the rediae, have such metachromatic film. It persists in its entirety for the remainder of the stay in the snail tissue, and sometimes the only demonstrable remnant of the peripheral mucoid envelop is observed. This film may be produced by discharging the mucoid materials from the mucoid gland as pointed out by Kruidenier, though its discharging process could not be observed under the microscope.

\section{Discussion}

It was reported by Kruidenier (1951, etc.) that the American cercariae, as far as he observed, possessed a series of mucoid gland without exception. All species of Japanese cercariae which were observed by us possessed also such mucoid 
gland. But there were many variations in the feature of mucoid gland among each species of cercariae. So it is desirable that as possible as many species of cercariae are observed about the mucoid gland in the future.

The above mentioned metachromatic substance is presumed a combination of hexosamine and protein moieties and either a mucopolysaccharide or a mucoid by Kruidenier. Many mucopolysaccharides and mucoids were effective inhibitors of proteolytic enzymes (Meyer, 1945). So we agree with Kruidenier's opinion that the discharge of their mucoid and the formation of the mucoid film initiating the final maturational changes of the cercariae may have mechanical and physiological functions. The further experiments are now being performed by us according to our idea that such materials must be analyzed more clearly by histochemical techniques.

\section{SUMMARY}

1. A detailed redescription of the cercaria of Centrocestus armatus, especially of its mucoid gland, was given.

2. Five pairs of mucoid glands were developed in the younger cercariae within redia. In the cercariae outside of redia, the mucoid film over the body surface was observed instead the gland cell.

3. The morphology and the function of such mucoid gland was discussed.

Sincere thanks are due to Dr. Y. Komiya, the Chief of Parasitology Division, National Institute of Health for his generous encouragement and reviewing the original manuscript.

\section{REFERENCES}

ANDO, R. (1918). Studies on the cercariae of Melania libertina from an endemic area of lung fluke in Gifu Prefecture (Addition of 6 species of cercariae). "Chuo Igaku Zasshi ", 141. $1-8$ (text in Japanese).

KOBAYASHI, H. (1918): Studies on the cercariae from Korea, 1. "Chosen Igakkai Zasshi ", $7(21), 19-80$ (text in Japanese).

KRUIDENIER, F, J. (1951): The formation and function of mucoids in virgulate cercariae, including a study of the virgulate organ. Am. Midl. Nat., 46, 660-683.

KRUIDENIER, F. J. (1953): The formation and function of mucoids in cercariae: Nonvirgulate xiphidiocercariae. Am. Midl. Nat., $5 O(1), 382-396$.

KRUIDENIER, F. J., (1953): The formation and function of mucoids in cercaria : Monostome cercariae. Am. Microscop. Soc., 72(1).

KRUIDENIER, F. J., (1953): Studies on the formation and function of mucoid gland in cercariae: Opisthorchoid cercariae. J. Parasitol., 39, 385-391.

KRUIDENIER, F. J. (1953): Studies on mucoid secretion and function in the cercaria of Paragonimus kellicotti Ward (Trematoda: Troglotrematidae). J. Morphol., 92, 531-543.

TAKAHASHI, S. (1929): A contribution to the life hystory of Stamnosoma armatum Tanabe. "Okayama Igakkai Zasshi", 41, 127-138.

TANABE, H. (1922): Studies on trematodes whose intermediate hosts are fresh water fishes, 1. Stamnosoma armatum n. g., n. sp. "Kyoto Igakkai Zasshi",, 19, 5-18 (text in Japanese).

YAmaguti, S. (1933): Studies on the helminth fauna of Japan, Part 1. Trematodes of birds, reptiles and mammals. Jap. J. Zool., 5, 72-74.

YAMAGUTI, S. (1938): Zur Entwicklungsgeschichte von Centrocestus armatus (Tanabe) mit besondere Berücksichtigung der Cercarie. Ztsch. für Parasitenk., 10, 293-296. 
YoKogaWA, M. and YoshimurA, H. (1956): Studies on "mucoid glands" in the cercaria of Paragonimus westermanii. Jap. J. Parasitol., 5, 449-456 (text in Japanese with English summary).

YOSHIDA, S. (1917): Studies on the cercariae of Melania spp. "Dobutsugaku Zasshi", 29, $1-17$ (text in Japanese). 